\title{
Junction Configuration Effects on the photovoltaic parameters of a-Si/CZTS solar cells
}

\author{
H. Bitam ${ }^{\mathrm{a}}$, B. Zaidi ${ }^{\mathrm{a}}$, B. Hadjoudja ${ }^{\mathrm{b}}$, C. Shekhar ${ }^{\mathrm{c}}$, S. Gagui ${ }^{\mathrm{b}}$, M. S. Ullah ${ }^{\mathrm{d}}$ \\ ${ }^{a}$ Department of Physics, Faculty of Matter Sciences, University of Batna 1, Batna, Algeria \\ ${ }^{b}$ Laboratory of Semiconductors, Department of Physics, University of Badji-Mokhtar, Annaba, Algeria \\ ${ }^{c}$ Department of Physics, Amity School of Applied Sciences, Amity University Gurgaon, Haryana, India \\ 122413. \\ ${ }^{d}$ Department of Electrical and Computer Engineering, Florida Polytechnic University, Lakeland, USA \\ *Corresponding author, email: zbeddiaf@gmail.com
}

\section{Abstract}

Due to increased energy intensive human activities resulting accelerated demand for electric power coupled with occurrence of natural disasters with increased frequency, intensity, and duration, it becomes essential to explore and advance renewable energy technology for sustainability of the society. Addressing the stated problem and providing a radical solution has been attempted in this study. To harvest the renewable energy, among variety of solar cells reported, a composite a-Si/CZTS photovoltaic devices has not yet been investigated. The calculated parameters for solar cell based on the new array of layers consisting of a-Si/CZTS are reported in this study. The variation of i) solar cell efficiency as a function of CZTS layer thickness, temperature, acceptor, and donor defect concentration; ii) variation of the open circuit current density as a function of temperature, open circuit voltage; iii) variation of open circuit voltage as a function of the thickness of the CZTS layer has been determined. There has been no reported study on a-Si/CZTS configuration-based solar cell, analysis of the parameters, and study to address the challenges imped efficiency of the photovoltaic device and the same has been discussed in this work. The value of the $\mathrm{SnO}_{2}$ /a-Si/CZTS solar cells obtained from the simulation is $23.9 \%$.

Keywords: CZTS, a-Si, Solar cells, SCAPS, Doping 


\section{Introduction}

Due to depleting non-renewable energy resources around the world [1], climate and sustainability concerns [2], demand for efficient and high-performance consumer electronics $[2,3]$, and rapid industrial growth [3], finding an innovative solution for energy generation becomes a significant concern and needs urgent attention. Solar cell technology has been one of the innovative solutions as an alternative to fossil fuels and nuclear energy [1-4]. A solar cell is a simple device consisting of $\mathrm{p}$ and n-type layers to form a $\mathrm{p}$-n junction that converts solar energy to electricity [5-7]. However, there are numerous challenges in current solar cell technology that needs to be addressed to achieve high efficiency. Currently, $90 \%$ of solar cell market belongs to silicon $(\mathrm{Si})$ based solar cells due to various advantages. The theoretical efficiency of solar cells e.g., dye-sensitized solar cells, traditional Si-based solar cells and other types of the solar cells is limited to approximately $30 \%$ [8, 9-10]. This is mainly due to i) poor absorption of incident light primarily because of completely transparent surface [5], ii) inappropriate material bandgap [8], and iii) low reflection within the device causing faster recombination of emitted electrons [8, 11]. As a result, a tandem cell is constructed from single-junction gallium arsenide (GaAs) and multi-junction (up to three p-n junctions) concentrators with different materials to absorb a larger spectrum of incident radiation [12]. However, the reported theoretical efficiency is $40.8 \%$ under radiation concentrations of 326 suns which is not possible for the practical condition [13]. The efficiency drops to $33.8 \%$ with one sun, and the process itself is not matured as in case of Si-based technology [8, 12]. To increase the efficiency, the probability of utilizing and integrating a-Si/CZTS based solar cells as a prospective material for constructing the solar cell is promising and have several advantages in the race for large-scale solar module production [14-16]. In this context, this 
study was designed with an objective to simulate and optimize the various physical and electrical parameters of a solar cell prepared from thin layers $\mathrm{CZTS}\left(\mathrm{Cu}_{2} \mathrm{ZnSnS}_{4}\right)$ to obtain good photovoltaic performance [17].

\section{Description of simulation parameters}

In this study, the physical and electrical parameters of a-Si/CZTS solar cell structure was simulated by the SCAPS software [18-19]. The details of the software can be found in the literature [20].

SCAPS is based upon solving of basic semiconductor equations including Poisson's equation (1) and continuity equations:

$$
\left\{\begin{array}{l}
\frac{\partial^{2}}{\partial x^{2}} \varphi(x)=\frac{q}{\varepsilon}\left[n(x)-p(x)-N_{D}^{+}(x)+N_{A}^{-}(x)-p_{t}(x)+n_{t}(x)\right] \\
\frac{\partial J_{n}}{\partial x}=G-R_{n} \\
\frac{\partial J_{p}}{\partial x}=G-R_{p}
\end{array}\right.
$$

The electron and hole current density is given by:

$$
\left\{\begin{array}{l}
J_{n}=q n \mu_{n} \frac{\partial \varphi}{\partial x}+q D_{n} \frac{\partial n}{\partial x} \\
J_{p}=-q p \mu_{p} \frac{\partial \varphi}{\partial x}+q D_{p} \frac{\partial p}{\partial x}
\end{array}\right.
$$

where, $\varphi$, electrostatic potential; $q$, electric charge; $\varepsilon$, permitivity of the free space; $n$, concentration of the free electrons; $\mathrm{p}$, concentration of the free holes; ${ }_{N_{D}^{+}}$, ionized doners like doping density; $N_{\bar{A}}$, ionized acceptors like doping density; $p_{t}$, density of the trapped holes; $n_{t}$, density of the trapped electrons; $G$, generation rate; $R$, recombination rate; $D_{n}$, electron diffusion cofficient; $\mathrm{D}_{\mathrm{p}}$ hole diffusion cofficient.

Poisson's equation relates electrostatic potential to charge whereas equation of continuity 
for holes and electrons. At the interfaces and contacts, appropriate boundary conditions are used to get coupled differential equations. These equations are solved to determine solar cell device parameters.

The simplified representation of the a-Si/CZTS solar cell simulated in the present study is given Figure 1. The composition of a-Si/CZTS cells from top to bottom in the cells are composed accordingly that include a transparent conductive film $(\mathrm{ZnO})$; layers of a-Si/CZTS, in the sequence, $\mathrm{n}$ then $\mathrm{p}$; and a substrate of Mo/glass. Note that the solar cell was studied under AM1.5, with $\mathrm{P}=100 \mathrm{~mW} / \mathrm{cm}^{2}$.

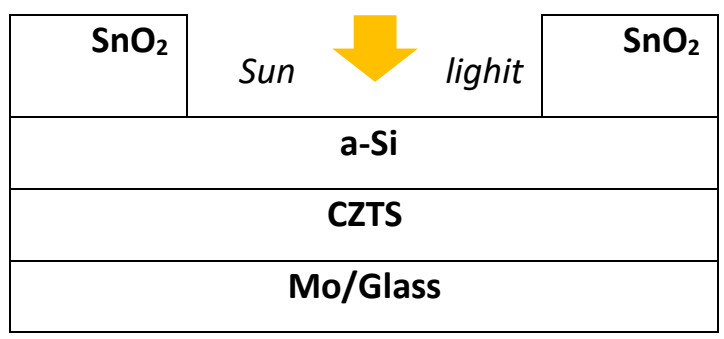

Figure 1 : Structure of solar cell studied

The main parameters critical for the simulation of the CZTS based solar cell are listed as a site in Table 1.

Table 1:Values of various material parameters used in the simulation

\begin{tabular}{|c|c|c|c|c||}
\hline S. No. & Sample parameter & CZTS & a-Si & SnO $_{2}$ \\
\hline 1. & thickness $(\mu \mathrm{m})$ & variable & 0.1 & 0.08 \\
\hline 2. & Gap energy $\mathrm{E}_{\mathrm{g}}(\mathrm{eV})$ & 1.5 & 1.8 & 3.6 \\
\hline 3. & Electronic affinity $(\mathrm{eV})$ & 4.21 & 3.9 & 4.55 \\
\hline 4. & Dielectric permittivity & 10 & 11.9 & 10 \\
\hline 5. & Density of states $\mathrm{BC}, \mathrm{N}_{\mathrm{c}}\left(\mathrm{cm}^{-3}\right)$ & $2.2 \times 10^{18}$ & $10^{20}$ & $4 \times 10^{18}$ \\
\hline 6. & Density of states BV, $\mathrm{N}_{\mathrm{v}}\left(\mathrm{cm}^{-3}\right)$ & $1.8 \times 10^{19}$ & $10^{20}$ & $9 \times 10^{18}$ \\
\hline 7. & Electron mobility $\left(\mathrm{cm}^{2} / \mathrm{V} . \mathrm{s}\right)$ & 100 & 20 & 100 \\
\hline
\end{tabular}




\begin{tabular}{|c|c|c|c|c||}
\hline 8. & Holes mobility $\left(\mathrm{cm}^{2} /\right.$ V.s $)$ & 20 & 5 & 25 \\
\hline
\end{tabular}

\section{Results and discussion}

The variation of the efficiency and short circuit current $\left(\mathrm{J}_{\mathrm{sc}}\right)$ as a function of the thickness of the CZTS layer in the range studied from 0.2 to $1.0 \mu \mathrm{m}$ is presented in Figure 2. The value of efficiency of the solar cell increases continuously with the increase in the thickness of the CZTS layer indicating the increased absorption of the light by the active layer. The maximum value of the efficiency obtained is 23.79 at the $1 \mu \mathrm{m}$ thickness. The increase in efficiency is rapid initially and thereafter it increases gradually in decreasing the saturation. efficiency increases with the increase in the thickness From the figure 2 it is also observed that, the shortcircuit current (Jsc) increases logarithmically to a maximum value of $30.02 \mathrm{~mA} / \mathrm{cm}^{2}$ at $10 . \mu \mathrm{m}$ thickness. The values of open circuit current reported in the literature [12] are lower than that obtained in the present study. The value of other material parameters of different layers such as the doping of the absorbent layer, the thickness and the doping of the buffer layer (a-Si) were constant.
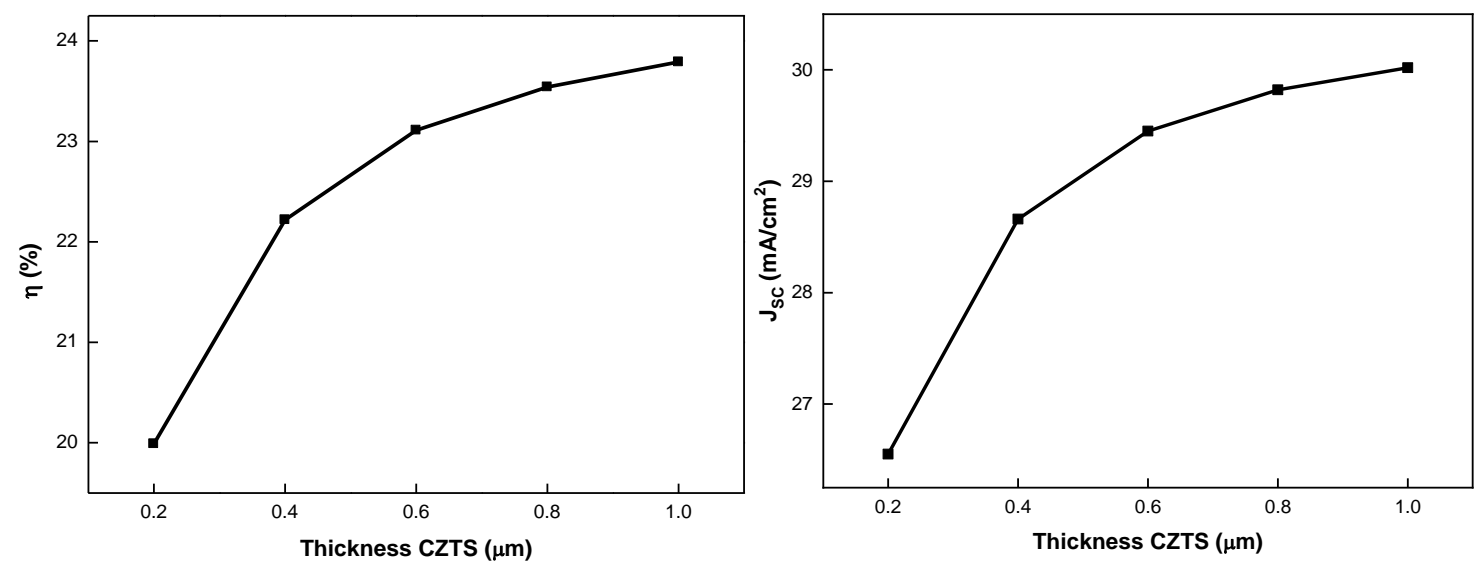

Figure 2: The variation of the efficiency and open circuit current as a function of thickness of the absorbent layer of CZTS. 
This study envisages to find the optimum thickness of the CZTS absorbent layer to obtain optimum operating characteristics of the a-Si/CZTS solar cell which is $1 \mu \mathrm{m}$. The currentvoltage characteristic of $\mathrm{SnO}_{2} / \mathrm{a}-\mathrm{Si} / \mathrm{CZTS}$ solar cells is presented in figure 3 . The improvement is mainly recorded in short-circuit current density $\left(\mathrm{J}_{\mathrm{sc}}\right)$ and the solar radiation conversion efficiency $(\eta)$ of the solar cell. The fill factor determined for the a-Si/CZTS solar cell is $85.81 \%$. The values obtained in the present study are higher compared to the values given in the literature owing to the geometrical arrangement of the layers [21].

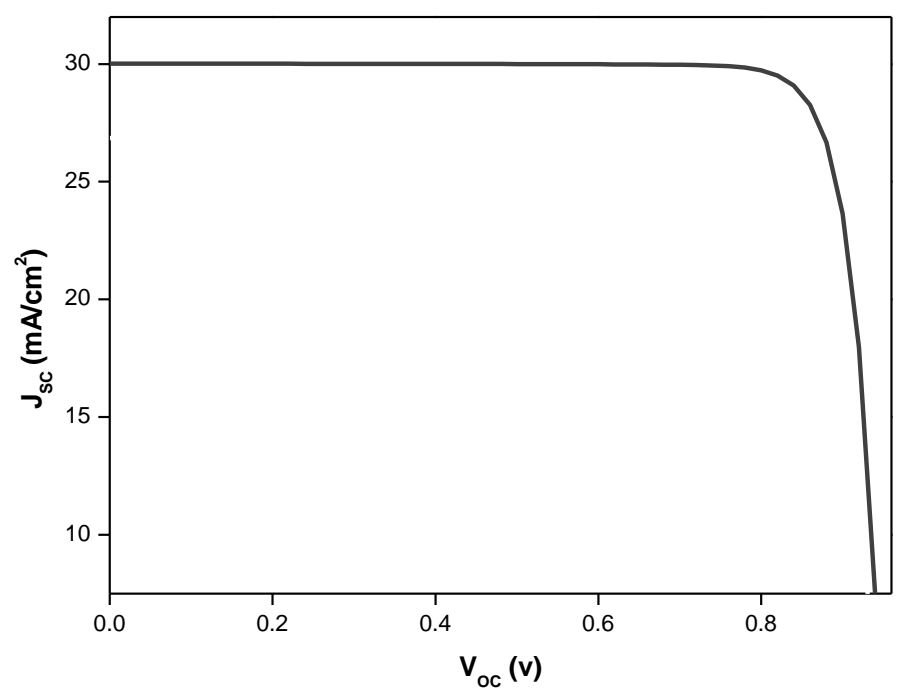

Figure 3: (I-V) curve of $\mathrm{SnO}_{2} / \mathrm{a}-\mathrm{Si} / \mathrm{CZTS}$ solar cells.

The photovoltaic parameters for $\mathrm{SnO}_{2} / \mathrm{a}-\mathrm{Si} / \mathrm{CZTS}$ solar cell configuration calculated from the $(\mathrm{I}-\mathrm{V})$ characteristics are: $\mathrm{V}_{\mathrm{oc}}(0.95$ Volt $), \mathrm{J}_{\mathrm{sc}}\left(30.02 \mathrm{~mA} / \mathrm{cm}^{2}\right), \mathrm{FF}(85.81 \%)$ and $\eta(23.9 \%)$.

The variation of efficiency ( $\eta$ ) and short-circuit current density (Jsc) as a function of temperature in the range from 280 to $320 \mathrm{~K}$ is presented in in figure 4 . There is a decrease in 
the values of short-circuit current density (Jsc) and efficiency ( $\eta$ ) of the solar cell with increasing temperature. The variation of open circuit voltage and efficiency with temperature is compared with the values given in the literature [22]. The value of efficiency decreases gradually from 23.90 up to $300 \mathrm{~K}$ and rapidly thereafter till the $320 \mathrm{~K}$ to a value of 23.10 . The trend representing the variation of efficiency is similar to as available in the literature but the values are significantly low. The open circuit voltage and short circuit current decreases almost linearly as a function of the temperature in the rage studied. The values of open circuit voltage reported in the literature [23] is higher with similar trend with the increase in temperature.
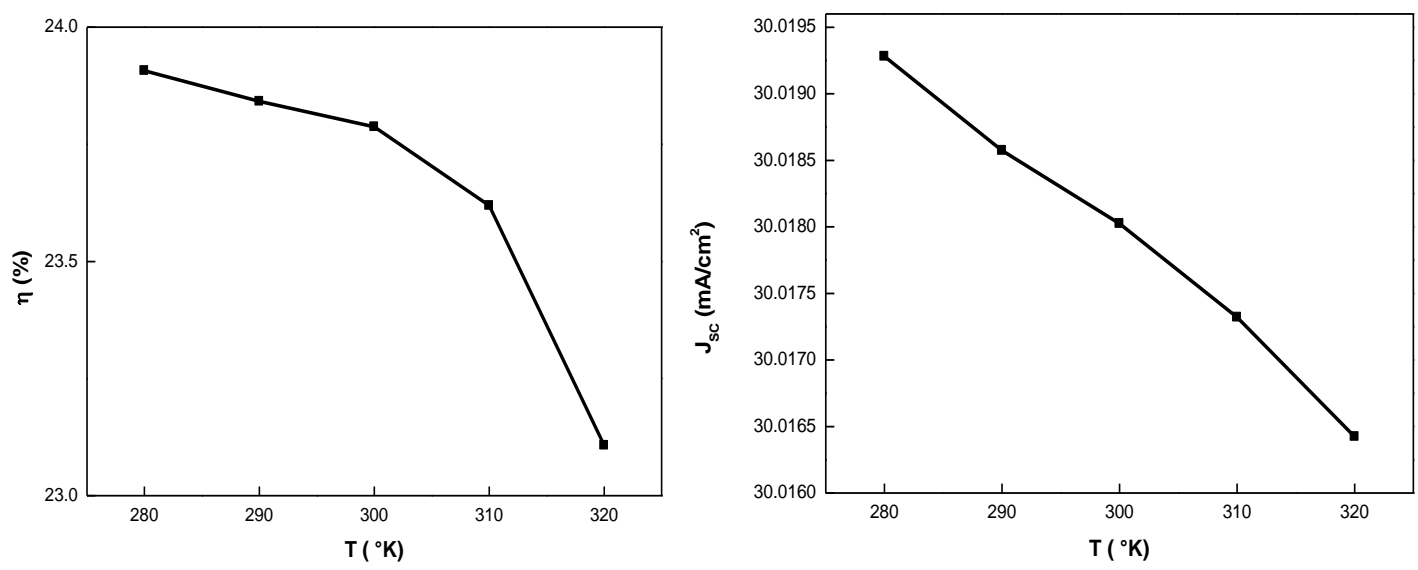

Figure 4: Effect of temperature on the of short-circuit current density (Jsc) and efficiency ( $\eta)$

The variation of efficiency as a function of donor carriers $\left(\mathrm{N}_{\mathrm{D}}\right)$ concentration in a-Si buffer layer is presented in figure 5. The donor carriers concentration has been varied between $10^{18}$ to $10^{21} \mathrm{~cm}^{-3}$ in the present study. It is observed that the efficiency increases with the increase in donor carriers density linearly. This increase in efficiency may be attributed to the enlargement of the space charge region which effectively increases the collection of charge carriers 
generated as a result of the absorption of energy from the electromagnetic radiation and subsequently increases the current generated from the $\mathrm{SnO}_{2} / \mathrm{a}-\mathrm{Si} / \mathrm{CZTS}$ solar cell.

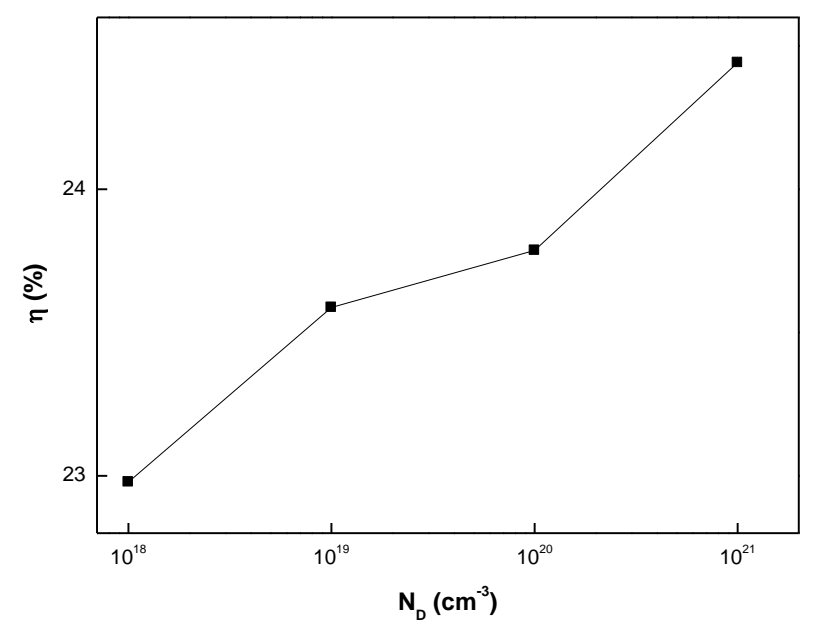

Figure 5: Influence of donor concentration on efficiency

The effect of acceptor concentration in absorbent layer of $\mathrm{SnO}_{2} / \mathrm{a}-\mathrm{Si} / \mathrm{CZTS}$ solar cell is presented in Figure 6. The acceptor carriers concentration has been varied between $10^{11}$ to $10^{14}$ $\mathrm{cm}^{-3}$ in the present study. It can be clearly observed that the efficiency increases linearly as a function of acceptor concentration in absorbent layer of $\mathrm{SnO}_{2} / \mathrm{a}-\mathrm{Si} / \mathrm{CZTS}$ solar cell. The increase in the efficiency can be assigned to the fact that with the rise in the acceptors $\left(\mathrm{N}_{\mathrm{A}}\right)$ in the absorbent layer in the solar cell, the rate of carrier recombination will decrease resulting in the better probability of charge carrier collection generated by photons in the electromagnetic radiation. 


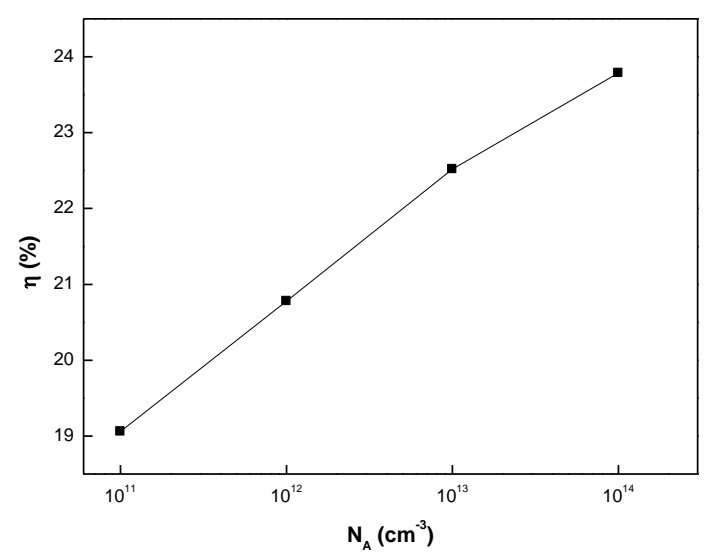

Figure 6: Effect of acceptor concentration on efficiency.

\section{Conclusion}

In this paper, simulation study has been undertaken on CZTS based solar cells using the SCAPS simulator. The effect of temperature change, variation of acceptor and donor concentration, series resistance, shunt resistance and of thickness of absorbent layer in of $\mathrm{SnO}_{2} / \mathrm{a}-\mathrm{Si} / \mathrm{CZTS}$ solar cell on the electrical characteristics has been studied. The values of electrical parameters obtained in this study are open circuit voltage $\left(\mathrm{V}_{\mathrm{oc}}=0.95 \mathrm{v}\right)$, the shortcircuit current density $\left(\mathrm{J}_{\mathrm{sc}}=30 \mathrm{~mA} / \mathrm{cm}^{2}\right)$, the fill factor $(\mathrm{FF}=85.8 \%)$ and the conversion efficiency $(\eta=23.8 \%)$.

\section{ACKNOWLEDGEMENTS}

The authors would like to express their sincere gratitude to Marc Burgelman and his team at the University of Ghent for providing access of SCAPS-1D.

Authors Contribution All of the authors contributed to the idea, simulation of the research, the analysis of the results, and the writing of the manuscript.

Funding No funding.

Data Availability Not applicable.

\section{Declarations}

Conflict of Interest Authors declare no conflict of interest that are directly or indirectly related to the work submitted for publication. 
Research Involving Human Participants or Animals Not applicable.

Informed Consent Not applicable.

Consent to Participate Not applicable.

Consent for Publication Not applicable.

\section{References}

\begin{tabular}{|c|c|}
\hline [1] & $\begin{array}{l}\text { Rasul MG, Azad AK, Sharma SC (2017) Clean Energy for Sustainable } \\
\text { Development. Academic Press, London. }\end{array}$ \\
\hline [2] & $\begin{array}{l}\text { Guilar NJ, Kleeburg TJ, Chen A, Yankelevich DR, Amirtharajah R (2009) } \\
\text { Integrated Solar Energy Harvesting and Storage. IEEE Trans Very Large Scale } \\
\text { Integr VLSI Syst. https://doi.org/10.1109/TVLSI.2008.2006792 }\end{array}$ \\
\hline [3] & $\begin{array}{l}\text { Stanley-Marbell P, Marculescu D (2007) An } 0.9 \text { x } 1.2 \text {, low power, Energy- } \\
\text { harvesting system with custom multi-channel communication interface. Design, } \\
\text { Automation \& \& Test in Europe Conference } \& \text { Exhibition. } \\
\text { https://doi.org/10.1109/DATE.2007.364560 }\end{array}$ \\
\hline [4] & $\begin{array}{l}\text { Slaoui A, Collins RT (2007) Inorganic Photovoltaic Solar Cells: Silicon and } \\
\text { Beyond MRS Bulletin, 32:211-218 }\end{array}$ \\
\hline [5] & 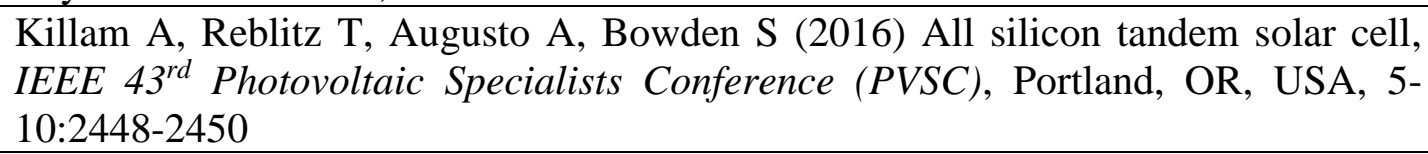 \\
\hline [6] & $\begin{array}{l}\text { Juneja S., Kumar S. (2020) Effect of Power on Crystallinity and Opto-Electronic } \\
\text { Properties of Silicon Thin Films Grown Using VHF PECVD Process. Silicon. } \\
\text { https://doi.org/10.1007/s12633-020-00697-7 }\end{array}$ \\
\hline [7] & $\begin{array}{l}\text { uneja S, Sharma M, Kumar S, (2019) Study of infra-red spectroscopy on bonding } \\
\text { nvironment and structural properties of Nanocrystalline silicon thin films grown by } \\
\text { HF-PECVD process. Silicon. https://doi.org/10.1007/s12633-018-0008-9 }\end{array}$ \\
\hline [8] & $\begin{array}{l}\text { aidi B, Saouane I, Shekhar C (2018) Electrical Energy Generated by Amorphous } \\
\text { ilicon Solar Panels. Silicon. https://doi.org/10.1007/s12633-017-9555-8 }\end{array}$ \\
\hline [9] & $\begin{array}{l}\text { Zaidi B, Ullah MS, Houaidji N, Gagui S, Hadjoudja B, Chouial B (2019) Role of } \\
\text { TCO Films in Improving the Efficiency of CdS/MoS } \mathrm{Meterojunction} \mathrm{Solar} \mathrm{Cells.} \mathrm{J.}_{2} \text {. } \\
\text { Nano-and Electronic Physics. https://doi.org/10.21272/jnep.11(2).02030 }\end{array}$ \\
\hline$[10]$ & $\begin{array}{l}\text { Zaidi B, Shekhar C, Kamli K, Hadef Z, Belghit S, Ullah MS (2020) Junction } \\
\text { Configuration Effects on the Performance of } \operatorname{In}_{2} \mathrm{~S}_{3} / \mathrm{CZTS} \text { Solar Cells. J. Nano- and } \\
\text { Electronic Physics 12: 01024-1-4 }\end{array}$ \\
\hline [11] & $\begin{array}{l}\text { Tune DD, Mallik N, Fornasier H, Flavel BS (2019) Breakthrough Carbon } \\
\text { Nanotube-Silicon Heterojunction Solar Cells. Adv Energy Mater 10: 1903261-1-6 }\end{array}$ \\
\hline [12] & $\begin{array}{l}\text { Subash KS, Chowdhury MH (2009) High efficiency carbon nanotube based solar } \\
\text { cells for electronics devices. Proceedings of the } 200912^{\text {th }} \text { International Symposium } \\
\text { on Integrated Circuits, Singapore }\end{array}$ \\
\hline [13] & $\begin{array}{l}\text { Geisz JF, Friedman DJ, Ward JS, Duda A, Olavarria WJ, Moriarty TE, Kiehl JT, } \\
\text { Romero MJ, Norman AG, Jones KM (2008) } 40.8 \% \text { efficient inverted triple-junction } \\
\text { solar cell with two independently metamorphic junctions. Applied Physics } \\
\text { letters. 10:123505 }\end{array}$ \\
\hline
\end{tabular}




\begin{tabular}{|l|l|}
\hline [14] & $\begin{array}{l}\text { Contento G, Lorenzi B, Rizzo A, Narducci D (2017) Efficiency enhancement of a- } \\
\text { Si and CZTS solar cells using different thermoelectric hybridization strategies. } \\
\text { Energy. 131: 230 -238 }\end{array}$ \\
\hline$[15]$ & $\begin{array}{l}\text { Song N, Green M, Huang J, Hu Y, Hao X (2018) Study of sputtered Cu2ZnSnS } \\
\text { thin films on Si. Applied Surface Science. 459: 700-706 }\end{array}$ \\
\hline$[16]$ & $\begin{array}{l}\text { Zaidi B, Zouagri M, Merad S, Shekhar C, Hadjoudja B, Chouial B (2019) Boosting } \\
\text { Electrical Performance of CIGS solar cells: Buffer layer effect. Acta Physica } \\
\text { Polonica A. 136: 988-991 }\end{array}$ \\
\hline$[17]$ & $\begin{array}{l}\text { Burgelman M, Nollet P, Degrave S (2000) Modelling polycrystalline semiconductor } \\
\text { solar cell. Thin Solid Films. 361-362: 527- 532 }\end{array}$ \\
\hline$[18]$ & $\begin{array}{l}\text { Decock K, Khelifi S, Burgelman M (2011) Modelling multivalent defects in thin } \\
\text { film solar cells. Thin Solid Films. 519: 7481- 7484 }\end{array}$ \\
\hline$[19]$ & $\begin{array}{l}\text { Burgelman M, Verschraegen J, Degrave S, Nollet P (2004) Modelling Thin-film PV } \\
\text { Devices. Progress in Photovoltaics: Research and Applications. 12:143-153 }\end{array}$ \\
\hline$[20]$ & $\begin{array}{l}\text { Burgelman M, Nollet P, Degrave S (2000) Modelling polycrystalline semiconductor } \\
\text { solar cells. Thin Solid Films. 361-362:527-532 }\end{array}$ \\
\hline [21] & $\begin{array}{l}\text { Contento G, Lorenzi B, Rizzo A Narducci D (2017) Efficiency enhancement of a-Si } \\
\text { and CZTS solar cells using different thermoelectric hybridization strategies. } \\
\text { Energy. https://doi.org/10.1016/j.energy.2017.05.028 }\end{array}$ \\
\hline$[22]$ & $\begin{array}{l}\text { Chowdhury A, Rahaman MM, Islam M, Rahman MM (2018) Effect of temperature } \\
\text { on CZTS based thin film solar cell performance. 35th European Photovoltaic Solar } \\
\text { Energy } \quad \text { and } \\
\text { https://doi.org/10.4229/35thEUPVSEC20182018-3BV.2.34 }\end{array}$ \\
\hline$[23]$ & $\begin{array}{l}\text { AlZoubi T, Moghrabi A, Moustafa M, Yasin S (2021) Efficiency boost of CZTS } \\
\text { solar cells based on double-absorber architecture: Device modeling and analysis. } \\
\text { Solar Energy. https://doi.org/10.1016/j.solener.2021.07.012 }\end{array}$ \\
\hline
\end{tabular}

